Eur. J. Clin. Chem. Clin. Biochem.

Vol. 32, 1994, pp. 31-36

(c) 1994 Walter de Gruyter \& Co.

Berlin - New York

\title{
Sex-Associated Differences in Protein 1 Values in Urine: Immunochemical Detection of Protein 1 in Genital Tissues
}

\author{
By Shuichi Ishii ${ }^{1}$, Yoshihisa Itoh ${ }^{1}$, Ryuta Okutani ${ }^{1}$, Tadashi Kawai ${ }^{1}$, Yutaka Kobayashi $^{2}$, Akihiko Tokue $^{2}$ and \\ Yasushi Asano ${ }^{3}$ \\ 1 Department of Clinical Pathology \\ 2 Department of Urology \\ 3 Department of Nephrology \\ Jichi Medical School, Japan
}

(Received May 26/October 13, 1993)

Summary: Immunochemical methods were used to analyse sex-associated differences in urinary protein 1 concentration. Spot urine from seven normal men and seven women of reproductive age was collected in four sequentially divided fractions, and protein 1 concentration in each fraction was measured by an enzyme immunoassay using the sandwich method: protein 1 values in the first of the sequential urine samples from the male subjects were remarkably high $(81.4 \pm 80.4 \mu \mathrm{g} / \mathrm{l}$; mean $\pm 1 \mathrm{SD})$, but were much lower in the remaining three fractions. In females, on the other hand, protein 1 values were low $(0.7 \pm 0.4 \mu \mathrm{g} / \mathrm{l})$, were uniform in all four sequential fractions, and were close to those of the last three fractions of urine from male subjects. Based on this finding, protein 1 concentration was measured in 14 specimens of seminal plasma, where concentration of protein 1 was high $(1259.1 \pm 1716.5$ $\mu \mathrm{g} / \mathrm{l}$; range, 201.9 to $6580.0 \mu \mathrm{g} / \mathrm{l})$. On Western blotting, protein 1 in seminal plasma had a molecular mass of $M_{\mathrm{r}} 14000$, the same as that of protein 1 purified from the urine of patients with chronic renal failure of probable plasma origin, and of concentrated male urine collected at the initiation of voiding, which is thus thought to come mainly from genital tissue.

Protein 1 was found to be in high concentration $(434.8 \pm 504.6 \mu \mathrm{g} / \mathrm{l})$ in five aspirated fluids collected at the ejaculatory duct after squeezing the prostate. Three prostate tissue extracts contained protein 1 concentrations ranging from 8.6 to $50.1 \mu \mathrm{g} / \mathrm{l}$. Protein 1 is also present in seminal vesicle fluids $(7.1 \pm 2.8 \mu \mathrm{g} / \mathrm{l}$; range, 2.3 to 9.5 $\mu \mathrm{g} / \mathrm{l})$. Indirect immunofluorescence showed no positive staining of the spermatozoa. All these results on the fractional clearance of protein 1 appear to indicate that protein 1 present in males originated from genital tissue as well as from plasma that had passed through the kidneys, while that present in females originated from the plasma only.

\section{Introduction}

Human protein 1 is a recently purified low molecular mass protein found in the urine. Sodium dodecyl sulphate polyacrylamide gel electrophoresis (SDS-PAGE) shows it to consist of a homodimer of a single polypeptide of $M_{\mathrm{r}} 7000$ (1). The authors have purified this protein from pooled urine from patients with chronic renal failure, characterized its physicochemical properties, and determined its partial amino acid sequences. Protein
1 was thus shown to be structurally identical to human lung Clara cell $M_{\mathrm{r}} 10000$ protein $(1,2)$. We prepared a monoclonal antibody and used it to develop an enzymelinked immunosorbent assay (ELISA), employing the sandwich method $(3,4)$.

This new assay, which was used to study the distribution of protein 1 in various body fluids (3), disclosed marked sex-associated differences in the concentration of protein 1 in spot urine: protein 1 values were higher in 
male than in female subjects of reproductive age, as first reported by Bernard et al. $(5,6)$. We then attempted to confirm this finding in the 24-hour urinary excretion from subjects of the same age group. Data obtained by studying protein 1 fractional clearance values (4) indicated that protein 1 may enter the urine through either the kidneys or the genitourinary tract.

We used various immunochemical methods to elucidate the mechanism that produces sex-associated differences in urinary protein 1 concentration. Our major finding was that protein 1 appears to originate not only from plasma, but also from genital tissues.

\section{Materials and Methods}

Sample preparation

Spot urine from seven normal men and women, 20 to 30 years of age, was collected in four sequentially divided samples. Twentyfour hour stored urine was separately collected in three sequential fractions over a period of two days from eight men, 20 to 25 years of age, and for one day from five women, 30 to 32 years of age. Paired serum samples were also collected from these individuals. Semen was obtained from 14 normal volunteers, 20 to 25 years old, after obtaining their informed consent. Each sample was immediately transferred to the laboratory and was centrifuged at $3000 \mathrm{~g}$ at room temperature for 20 minutes soon as it was obtained in the moming. For immunofluorescence study, the resulting sperm pellet was further washed with $0.05 \mathrm{~mol} / \mathrm{l}$ phosphate buffered saline $(\mathrm{pH} 7.2)$, then centrifuged again under the same conditions. This process was repeated three times. Aspirates collected at the ejaculatory duct, as well as seminal vesicle fluids, were obtained from five patients with bladder cancer on total cystectomy. The prostate-protein rich fluid was collected by aspirating the ejaculatory duct after squeezing the prostate. Seminal vesicle fluid was obtained by collecting stored fluid in an incised tissue. Prostate tissue extract was obtained from these patients. Then $200 \mathrm{mg}$ of prostate tissue from each of the three patients was minced with a cutter, homogenized in a tissue homogenizer (Hiraguri Kagaku, Tokyo), and suspended in $200 \mu \mathrm{l}$ of $0.05 \mathrm{~mol} / \mathrm{l}$ phosphate buffered saline. Protein 1 concentration was expressed in $\mu \mathrm{g} / \mathrm{l}$. In order to eliminate the effects of contaminating DNA on SDS-PAGE, seminal plasma was treated with $400 \mathrm{mg} / 1$ DNase $\left.\mathrm{I}^{\mathrm{l}}\right)(2490 \mathrm{U} / \mathrm{mg}$, Worthington Biochemical, New Jersey) at $37^{\circ} \mathrm{C}$ for 10 minutes after dialysing against phosphate buffered saline overnight and centrifugation at $10000 \mathrm{~g}$ for 5 minutes.

\section{Quantitation of protein 1}

Protein 1 concentration was determined, in accordance with the established method, by an enzyme-linked immunosorbent assay, employing the sandwich method (4). The wells of a plastic plate (Nunc, Copenhagen) were coated with a monoclonal antibody. Diluted sample or purified standard $(100 \mu \mathrm{l})$ was then added to each well and incubated for 90 minutes at $37^{\circ} \mathrm{C}$. After washing with $0.05 \mathrm{~mol} / \mathrm{l}$ phosphate buffered saline containing $0.5 \mathrm{ml} / 1$ Tween -20 (washing buffer), $100 \mu \mathrm{l}$ of properly diluted anti-protein 1 rabbit antibody (DAKO, Copenhagen) was added and allowed to react at $37^{\circ} \mathrm{C}$ for 90 minutes. The same buffer was then used to repeat the

\footnotetext{
l) Enzymes:

DNase I (EC 3.1.4.5)

Peroxidase (EC 1.11.1.7)

Phospholipase $\mathrm{A}_{2}$ (EC 3.1.1.4)
}

washing; next, $100 \mu \mathrm{l}$ of horseradish peroxidase')-conjugated goat anti-rabbit IgG antibody (DAKO) was added, and the sample was incubated at $37^{\circ} \mathrm{C}$ for another 90 minutes. After a third washing with the same buffer, $100 \mu \mathrm{l}$ of $1 \mathrm{~g} / 1$ of 0 -phenylene diamine in citratc buffer at a $\mathrm{pH}$ of 5.0 , containing $0.3 \mathrm{ml} / 1$ hydrogen peroxide, was added. The reaction was terminated by adding $150 \mu \mathrm{l}$ of $1 \mathrm{~mol} / \mathrm{l}$ sulphuric acid, and enzymatic activity was determined by measuring the absorbance at $492 \mathrm{~nm}$. Purified protein 1 was used as a standard, and its concentration was determined by Coomassie protein assay reagent (Pierce, Illinois), with bovine serum albumin as standard. The molecular extinction coefficient of purified protein 1 at $10 \mathrm{~g} / 1$ was 6.0 at $280 \mathrm{~nm}$. Sensitivity of the ELISA is $5 \mathrm{ng} / \mathrm{l}$ and the actual quantitative range is from $50 \mathrm{ng} / \mathrm{l}$ to $5000 \mathrm{ng} / \mathrm{l}$.

\section{Other procedures}

Serum and urinary creatinine was measured using the method of Jaffé.

\section{Western blotting}

SDS-PAGE was performed according to Okutani et al., using $10 \%$ polyacrylamide gel (2). The separated proteins were electrophoretically transferred to a polyvinylidine difluoride membrane (Millipore, Tokyo), on which an immunoenzymatic reaction was performed to detect protein 1, using the monoclonal antibody as a first antibody and peroxidase-conjugated goat anti-mouse IgG antibody (DAKO) as a second antibody. An immunostaining kit (Konica, Tokyo) was used for visualization.

\section{Indirect immunofluorescence}

Sperm was reacted at $4{ }^{\circ} \mathrm{C}$ for 30 minutes with the monoclonal antibody in $0.05 \mathrm{~mol} / \mathrm{l}$ phosphate buffered saline ( $\mathrm{pH} 7.2$ ). After three cycles of washing and centrifugation at $3000 \mathrm{~g}$ for $20 \mathrm{mi}$ nutes, fluoroisothiocyanate-conjugated anti-mouse IgG (DAKO) was reacted at $4^{\circ} \mathrm{C}$ for 30 minutes, followed by three cycles of washing and centrifugation. Cells were then observed under fluoroscopy (Olympus, Tokyo).

\section{Results}

\section{Protein 1 value among four sequentially divided fractions in spot urine}

For the seven normal males, protein 1 concentration in the first voided fraction was the highest of the four sequential fractions: $81.4 \pm 80.4 \mu \mathrm{g} / 1$ (mean $\pm 1 \mathrm{SD}$ ); its highest value was $220.3 \mu \mathrm{g} / \mathrm{l}$. In the second sequential urine fraction, it was markedly lower, $8.8 \pm 7.3 \mu \mathrm{g} / \mathrm{l}$; and in the third and fourth fractions, the concentrations were as low as $2.6 \pm 1.6 \mu \mathrm{g} / \mathrm{l}$ and $2.3 \pm 1.3 \mu \mathrm{g} / \mathrm{l}$, respectively, which were close to the values obtained found for female subjects (see below). In the seven female subjects, the concentration of protein 1 was much lower than that of the first fraction obtained from the male subjects, $0.7 \pm 0.4 \mu \mathrm{g} / \mathrm{l}$, and remained constantly low in all four fractions: $0.8 \pm 0.5 \mu \mathrm{g} / 1$ (fig. 1).

\section{Protein 1 value in 24-hour stored urine collected separately in three fractions}

All urine used here had been voided into three sequentially separate fractions, each of which was stored for 

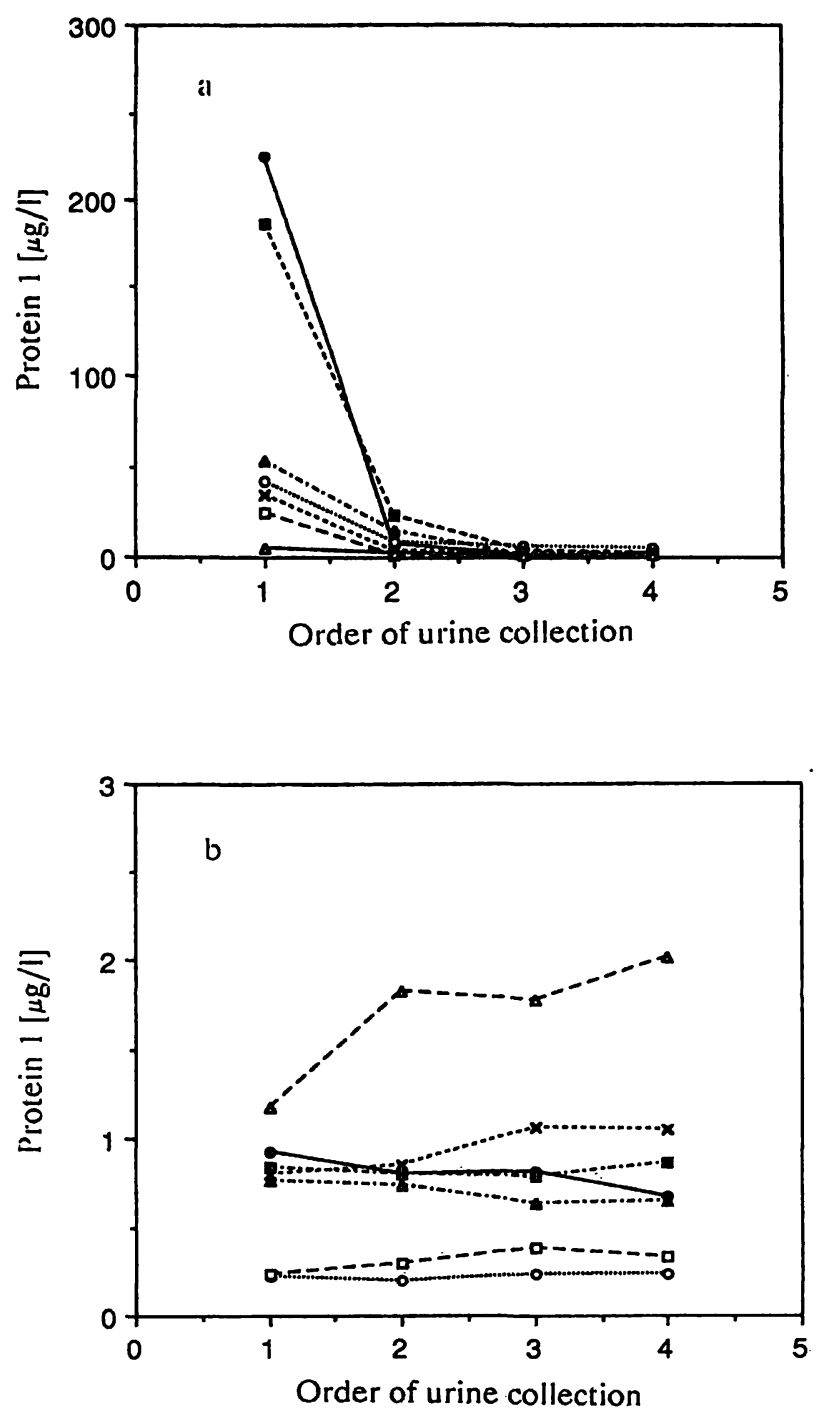

Fig. 1 Protein 1 values of four sequentially collected urine samples from seven normal males (a) and seven normal females (b).

-0- No 1, -O- No 2, - X- No 3, ---ם-- No 4, ..--A.-. No 5, --口-- No 6, $-\Delta-$ No 7

24 hours for 2 consecutive days. The volumes of the three fractions consecutively collected were $45.9 \pm 6.4$ $\mathrm{ml}$ (first fractions), $1045.3 \pm 25.8 \mathrm{ml}$ (second fractions) and $44.3 \pm 6.2 \mathrm{ml}$ (third fractions) in men, and 49.5 $\pm 4.2 \mathrm{ml}$ (first fractions), $945.0 \pm 429.3 \mathrm{ml}$ (second fractions), and $50.3 \pm 6.2 \mathrm{ml}$ (third fractions) in women. The variation in protein 1 concentration was same as that in spot urine. In males, the protein 1 value of 102.2 $\pm 93.3 \mu \mathrm{g} / 1$ in the first fractions contrasted sharply with those of the second $(5.3 \pm 2.0 \mu \mathrm{g} / \mathrm{l})$ and last fractions $(3.7 \pm 1.3 \mu \mathrm{g} / \mathrm{l})$. In contrast, values in females were much lower, averaging 2.0 to $2.2 \mu \mathrm{g} / \mathrm{l}$; values in the three fractions did not differ significantly. Similarly, urine creatinine concentration, used as a control, was almost the same in all three fractions in both the male and the female subjects. Protein 1 concentration in the last fraction voided by males reflects protein 1 values of ur- ine stored in the bladder and is probably of plasma-kidney origin, while protein 1 in the first fraction originates primarily from the bladder as well as from the urethra, the genital tissues, or both. Based on the urinary volume and protein 1 concentration of each collected fraction, 24-hour excretion of protein 1 from each source was calculated after determining 24-hour protein 1 excretion in each of the three fractions (fig. 2). Our results indicate that protein 1 originating from the plasma and kidneys had a concentration of $4.1 \pm 1.3 \mu \mathrm{g} / \mathrm{day}$, while that derived from the urethra, the genital tissues, or both, had a concentration of $5.8 \pm 3.1 \mu \mathrm{g} /$ day. The ratio between the two fractions was $0.98 \pm 0.82$ and ranged from 0.43 to 2.06. The level of excretion and inter-fraction ratio did not vary significantly in any of the subjects.

\section{Re-evaluation of fractional clearance of protein 1}

Using urine collected in three sequential fractions on each voiding and then stored for 24 hours, we calculated concentrations of protein 1 from two different sources in males: the bladder and the genital tissues. Twentyfour-hour urinary excretion averaged $4.1 \mu \mathrm{g} /$ day in the bladder and $5.8 \mu \mathrm{g} /$ day in other genital tissues. Actual protein 1 fractional clearance in the kidney was thus reevaluated by using the protein 1 value obtained from urine of bladder origin. Protein 1 fractional clearance was almost the same as that in females and was close

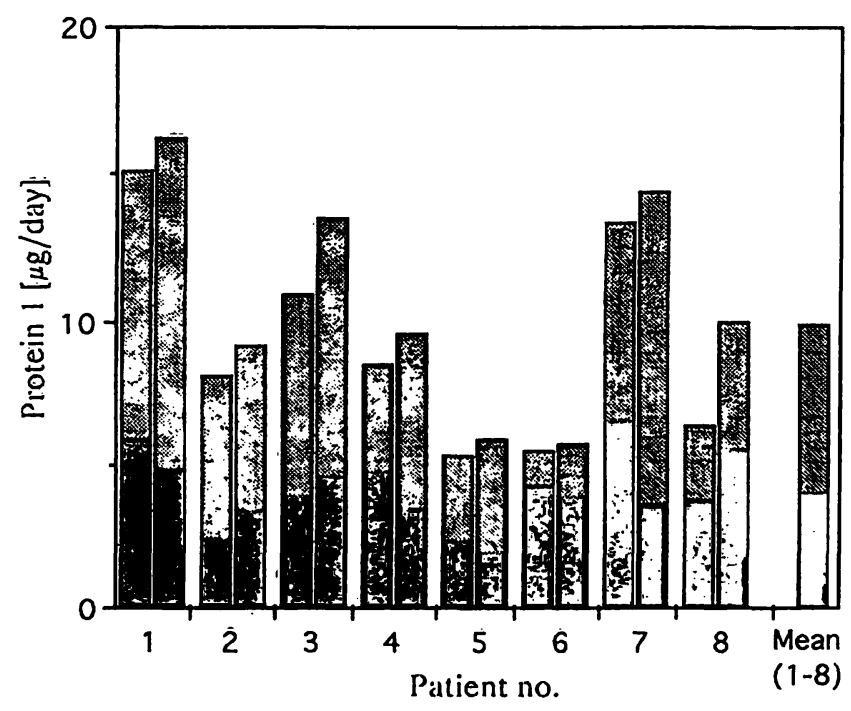

Fig. 2 Protein 1 concentration in 24-hour stored urine, calculated by protein 1 concentration from three divided fractions from normal males. Left bar represents the first day; right bar, the second day.

图: protein 1 originating from genitourinary tract

: protein 1 originating from kidncy 
to the fractional clearances of $\alpha_{1}$-microglobulin and $\beta_{2}$ microglobulin (tab. 1).

Protein 1 concentration in the seminal plasma, aspirated fluids at the ejaculatory duct, and seminal-vesicle fluids

Protein 1 concentration in seminal plasma from 14 normal men was remarkably high: $1259 \pm 1716.5 \mu \mathrm{g} / \mathrm{l}$; range, 201.9 to $6587.0 \mu \mathrm{g} / \mathrm{l}$. The value in aspirates from the ejaculatory duct, obtained from five patients with bladder cancer on cystectomy, produced remarkably high concentrations: $434.8 \pm 504.6 \mu \mathrm{g} / \mathrm{l}$; range, 97.1 $\mu \mathrm{g} / \mathrm{l}$ to $1311 \mu \mathrm{g} / \mathrm{l}$. Furthermore, the protein 1 concentrations in three tissue extracts of prostate were 8.6, 20.3 , and $50.1 \mu \mathrm{g} / \mathrm{l}$, respectively. The concentration of protein 1 in four samples of seminal vesicle fluids was low, and equal to that in normal urine: $7.1 \pm 2.8 \mu \mathrm{g} / \mathrm{l}$, range $2.3-9.5 \mu \mathrm{g} / \mathrm{l}$.

\section{Seminal plásma on Western blotting}

After digestion with DNase I, seminal plasma containing $3170 \mu \mathrm{g} / \mathrm{l}$ protein 1 was applied to SDS-PAGE. On Western blots of seminal plasma, a single, clear, discrete band was observed reacting with the monoclonal antibody at a molecular mass of $M_{\mathrm{r}} 14000$. This band migrated to exactly the same position as that produced by purified protein 1 and by concentrated urine collected in the first fraction of voiding (fig. 3). Because no other positive band was observed, the presence of lighter and heavier forms can be ruled out in both seminal plasma and urine.

\section{Protein 1 in spermatozoa}

No positive staining was obtained by indirect immunofluorescence on the surface or in the cytoplasm of spermatozoa (data not shown).

\section{Discussion}

Bernard et al., using a latex immunoassay with both standard sera and antisera from DAKO (5), were the

Tab. 1 Actual fractional clearance of protein 1 in the kidneys calculated from the data obtained from three sequentially divided fractions of 24-hour stored urine.

\begin{tabular}{lll}
\hline & Male & Female \\
\hline Protein 1 (uncorrected) & $0.0102 \pm 0.0007$ & $0.0005 \pm 0.0006$ \\
Protein 1 (actual) & $0.0020 \pm 0.0008$ & $0.0013 \pm 0.0019$ \\
$\beta_{2}$-Microglobulin & $0.0005 \pm 0.0002$ & $0.0005 \pm 0.0001$ \\
$\alpha_{1}$-Microglobulin & $0.0012 \pm 0.0005$ & $0.0005 \pm 0.0002$ \\
\hline
\end{tabular}

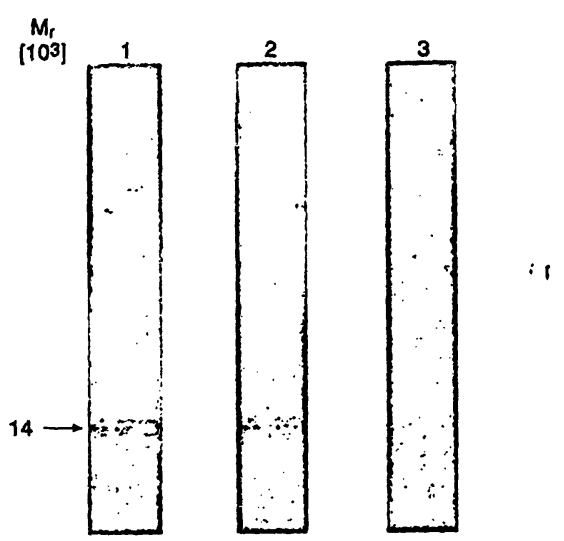

Fig. 3 Immunochemical detection of protein 1 in seminal plasma on Western blots.

Lane 1: Purified protein 1; Lane 2: Concentrated urine collected in the first sequential fraction; Lane 3: Seminal plasma.

Seminal plasma was treated with DNase I, while purified protein 1 and collected urine were undigested.

first to show that protein 1 concentration in spot urine was higher in males than in females. We further confirmed this sex-associated difference in spot urine, as well as in 24-hour stored urine from individuals in the same age group, using a new ELISA. The new ELIISA employs the sandwich method, uses purified protein 1 as a standard, and also uses a monoclonal antibody that was prepared by the authors (4). The sex-associated difference appeared at adolescence and became much more pronounced in adults in their reproductive years, indicating a probable association with regulation by sex-dependent factors or sex hormones. Increased urinary excretion of protein 1 after infusion with $L$-arginine (7), and a marked elevation in the serum concentration of protein 1 (3) in patients with renal glomerular dysfunction clearly indicate that plasma is a source of urinary protein 1 , as is the case with $\alpha_{1}$-microglobulin, $\beta_{2}$-microglobulin, and low molecular mass proteins. Its fractional clearance in males is extraordinarily high (up to $1 \%$ ), whereas in females it is only about $0.01 \%$, almost the same as the fractional clearance of $\alpha_{1}$-microglobulin and $\beta_{2}$-microglobulin. This suggests that protein 1 in males is secreted into the urine by either the kidneys or the genitourinary tract.

To identify the site or sites of protein 1 secretion, we used immunochemical methods to systematically pursue the source of this protein, and to determine whether it originated from genital tissue. We measured protein 1 concentrations in urine samples collected in four sequential fractions: the protein 1 concentration in the first fractions voided by males was much higher than that in the remaining three fractions. In contrast, the concentration of protein 1 in urine samples voided by women was much lower and remained constant in all 
four fractions. This convincingly demonstrates that protein 1 in males also originates from the genital organs or the urethra. As expected, a high concentration of protein 1 was found in the seminal plasma. Western blots show the molecular mass of protein 1 to be identical to that of purified protein 1 and protein 1 present in urine. No other bound form was detected. Spermatozoa did not give a positive immunofluorescent stain for protein 1 , and no further attempt was made to find protein 1 in spermatozoa. Further immunochemical studies demonstrated high concentrations of protein 1 in aspirated fluids at the ejaculatory duct, obtained after squeezing the prostate. Moreover, an elevated value of protein 1 was found in prostate tissue extract in one individual. The data presented here suggest that among genitourinary tissues, the prostate might be a source of protein 1 . A recent preliminary histological examination indicated the presence of this protein in some part of the prostate epithelium. Rabbit uteroglobin, which shows $61 \%$ primary sequence homology with protein 1 or human lung Clara cell $M_{\mathrm{r}} 10000$ protein $(1,2,6)$, was purified from rabbit uterine lavage, and its goat antibody was prepared. Indirect immunofluorescence showed localization of this protein in the human prostate (8), which lends further support for the possible presence of protein 1 in this gland. Many different kinds of proteins are known to be produced in the seminal vesicle. Although the concentration of protein 1 was low in fluids stored in incised seminal vesicle, this tissue may be a major source of protein 1 in semen. Synthesis and secretion by the ejaculatory duct may also be possible. Further study will be necessary to immunohistochemically identify the synthetic site in the genital tissues.

Bernard et al. have recently shown the presence of antigenetically identical protein 1 in semen by Ouchterlony immunodiffusion. They have, however, not found this protein in homogenate of prostate and seminal vesicles (6). Both assay system and specificity of antibody seem satisfactory. Choice of samples examined and sensitivity of the assay may account for the differences between their results and ours.

By calculating concentrations of protein 1 from two different sources in males, the bladder and other genital tissues, the actual protein 1 fractional clearance in the kidney was re-evaluated and was shown to be almost the same as that in females, and was close to that of $\alpha_{1}$ - microglobulin and $\beta_{2}$-microglobulin (tab. 1). This strongly suggests that protein 1 stored in the bladder comes from the plasma and is passed through the kidneys, clearly reflecting renal glomerulotubular function. Like other low molecular mass proteins, protein 1 is difficult to use as an indicator of renal function, because its concentration is difficult to evaluate in whole urine, but it may be possible to use it if the urine sample is collected at the end of voiding. Results of the present study also indicate that urine collected at intermediate voiding could also be so used. Urine collected from females and children before puberty at any stage of voiding can be used without restriction, because all of the protein 1 in the urine originates in the kidney. To obtain accurate results, subjects of either sex should avoid physical exercise before urine collection. Even riding a bicycle, for example, compresses genital tissues and could affect levels of protein 1 in males.

Protein 1 at initial voiding in adult males seems to be derived mainly from genital tissues. We recently encountered extraordinarily elevated concentrations of protein 1 at initial voiding in some patients with prostate cancer. Determination of protein 1 concentrations in sequential urine fractions might, therefore, prove useful in the evaluation of physiological and pathological events in the kidney and genital tissues. The inclusion of this protein as one of several other markers in urinary protein profiles may improve the diagnostic and prognostic power of current surveillance measures.

Human lung Clara cell $M_{\mathrm{r}} 10000$ protein, structurally identical with protein 1 , has been found to inhibit phospholipase $A_{2}{ }^{1}$ ) activity (9). Phospholipase $A_{2}$ is rich in seminal plasma (10). It is distributed in the prostate and spermatozoa in humans (10) and, additionally, in the seminal vesicles and Cowper's glands of bulls (11). Protein 1 might play an important role in the regulation of the reproductive system through its action as a phospholipase $A_{2}$ inhibitor. Efforts will now be directed to the elucidation of the functional aspects of this protein.

\section{Acknowledgement}

This work was supported by a Grant-in-Aid from the Ministry of Education (Project No. 02454490) and a Research Grant from the Specific Diseases Division from Progressive Renal Disorders, Ministry of Health and Welfare, Japan. The authors are also grateful to Ms Tomomi Kebukawa for her excellent technical assistance.

\section{References}

1. Jackson, P. J., Turner, R., Keen, J. N., Brooksbank, R. A. \& Cooper, E. H. (1988). Purification and partial amino acid sequence of human urine protein 1. J. Chromatogr. 452, 359367.

2. Okutani, R., Itob, Y., Hirata, H., Kasahara, T., Mukaida, N. \& Kawai, T. (1992) Simple and high-yield purification of urine protein 1 using immunoaffinity chromatography: Evidence for the identity of urine protein 1 and human Clara cell 10-kilodalton protein. J. Chromatogr. 577, 25-35. 
3. Itoh, Y., Ishii, S., Okutani, R. \& Kawai, T. (1992) Purification of urine protein 1 (UP 1) from urine: An initial study toward clinical application. Progress in Clinical Biochemistry, pp. $307-311$.

4. Ishii, S.. Itoh, Y., Okutani, R., Asano, Y. \& Kawai, T. (1993) Development of an enzyme-linked immunosorbent assay for protein 1. Contr. Nephrol. 101, 71-77.

5. Bernard, A. M., Lauwerys, R. R., Noël, A., Vandeleene, B. \& Bernard, R. R. (1989) A sex-dependent marker of tubular or glomerular dysfunction. Clin. Chem. 35, 2141-2142.

6. Bernard, A., Roels, H., Lauwerys, R., Witters, R., Gielens, C., Soumillion, A., Damme, J. V. \& Ley, M. D. (1992) Human urinary protein 1: Evidence for identity with the Clara cell protein and occurrence in respiratory tract and urogenital secretions. Clin. Chim. Acta 207, 239-249.

7. Itoh, Y., Muto, S., Okutani, R., Ishii, S., Asano, Y. \& Kawai, $T$. (1992) Increased urinary excretion of urine protein 1 induced by L-arginine monohydrochloride. Nephron 62, 467468.
8. Manyak, M. J., Kikukawa, T. \& Mukherjee, A. B. (1988) Expression of a uteroglobin-like protein in human prostate. J. Urol. 140, 176-182.

9. Gurmukh, S., Sikandar, L. K., William, E. B., Amy, L. K., Ushasi, S. \& Mari-Low Wong-Chong (1990) Clara cell $10 \mathrm{kDa}$ protein $(\mathrm{CCl})$ : Comparison of structure and function to uteroglobin. Biochim. Biophys. Acta 1039, 348-355.

10. Ronkko, S. \& Rasanen, M. (1992); Studies on phospholipase $\mathrm{A}_{2}$ in human seminal plasma. Int. J. Biochem. 24, 987-992.

11. Ronkko, S., Lahtinen, R. \& Vanha-Perttula, T. (1991) Phospholipase $A_{2}$ in the reproductive system of the bull. Int. J. Biochem: $23,595-603$.

Dr. S. Ishii (c/o Dr. Y. Itoh)

Department of Clinical Pathology

Jichi Medical School

Minami-Kawachi-Machi

Tochigi-Ken

Japan 